\title{
One-Pot Synthesis of Metallopyrazinoporphyrazines Using 2,3-Diaminomaleonitrile and 1,2-Dicarbonyl Compounds Accelerated by Microwave Irradiation
}

\author{
Ali Maleki ${ }^{1}$ and Ali Hossein Rezayan ${ }^{2}$ \\ ${ }^{1}$ Department of Chemistry, Iran University of Science and Technology, Tehran 16846-13114, Iran \\ ${ }^{2}$ Department of Life Science Engineering, Faculty of New Sciences and Technologies, University of Tehran, Tehran 14395-1561, Iran \\ Correspondence should be addressed to Ali Maleki; maleki@iust.ac.ir
}

Received 30 October 2013; Revised 7 January 2014; Accepted 28 January 2014; Published 27 February 2014

Academic Editor: Vito Ferro

Copyright (C) 2014 A. Maleki and A. H. Rezayan. This is an open access article distributed under the Creative Commons Attribution License, which permits unrestricted use, distribution, and reproduction in any medium, provided the original work is properly cited.

A one-pot microwave-assisted synthesis of metallopyrazinoporphyrazines as porphyrazine derivatives carrying six-membered pyrazine rings annulated at the periphery of the tetrapyrrolic macrocycle is described starting from 2,3-diaminomaleonitrile, 1,2dicarbonyl compounds, metal salts, and urea.

\section{Introduction}

Tetrapyrrolic macrocycles of porphyrins, phthalocyanines, and related compounds, modified by the attachment of peripheral substituents, have attracted significant attention for many years because of their industrial applications in diverse areas, especially in modern technologies [1-4], such as elaboration of Langmuir-Blodgett films [5-7], chemical sensors $[8,9]$, nonlinear optical materials [10-12] biomedical agents for diagnosis, and therapy [13] as well as sensitizers in solar cells [14-16].

Porphyrazines (Pzs), as an important class of phthalocyanine analogues or porphyrinoid macrocycles, carrying heterocyclic rings, such as diazepine, pyridine, and pyrazine rings, directly annulated to the pyrrole rings of the porphyrazine core, have been presented in recent years as optical agents with clear advantages over the porphyrins [17-25]. Porphyrins are either naturally occurring molecular systems or original synthetic products, whereas Pzs are derived exclusively from synthetic laboratory work. An area of further expansion of new Pzs macrocycles can be directed to the synthesis of new phthalocyanines-like macrocycles opening a route to new forms of investigation and promising potential practical applications [26].
Metal complexes of Pzs (MPzs) ligands have been at the focus of interest because of their high electronic delocalization, biological significance, and numerous potential technological applications such as electronic, magnetic, photophysical, and photosensitizing properties of Pzs [27-31]. It has been found that functional groups fused to the peripheral positions of MPzs are integrated to the macrocyclic core more effectively than that of phthalocyanines [32-34]. It implies that the modification of the structure influences the photosensitizing properties [35].

There are only a few reports for the synthesis of Pzs under mild and efficient conditions. On the other hand, attempts for direct synthesis of Pzs carrying unprotected vicinal $\mathrm{NH}_{2}$ groups from 2,3-diaminomaleodinitrile were unsuccessful [17-20]. Due to the importance of these macrocycles, introduction of new, efficient, and inexpensive protocol for this purpose is of prime importance.

Microwave-assisted organic reactions are well known as environmentally benign transformations that can improve a diverse area of chemical processes. In particular, the reaction time and energy input of these processes are assumed to be mostly reduced in comparison with reactions of a long duration at high temperatures under conventional heating conditions [36]. 


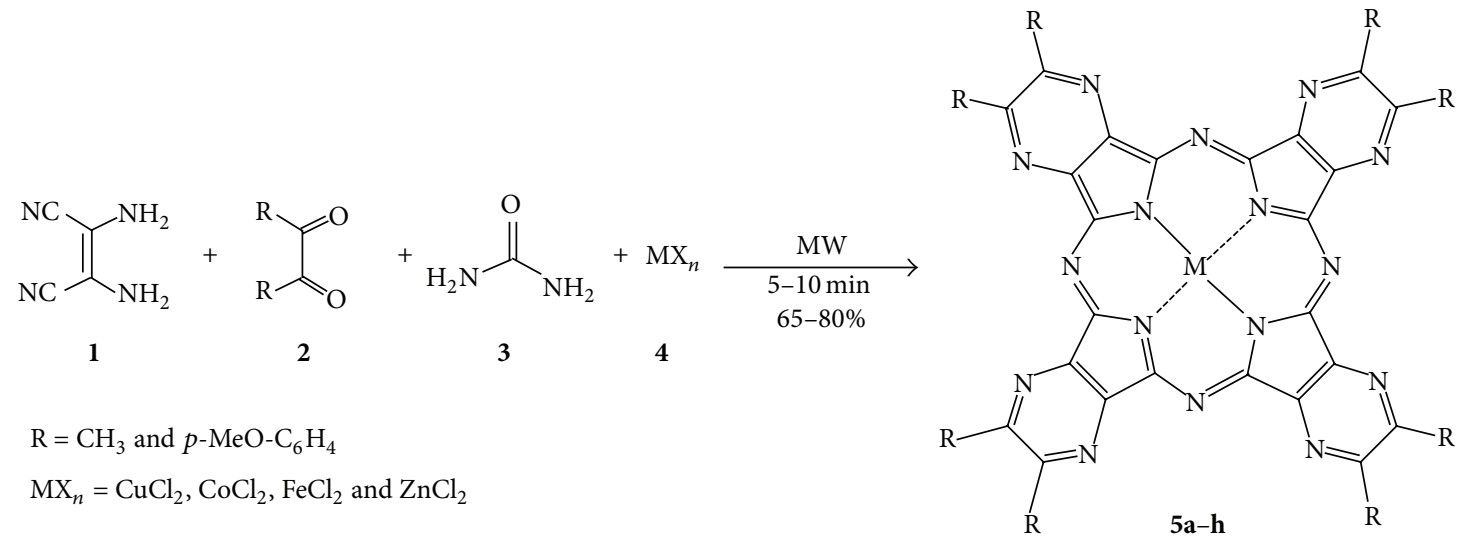

SCHEME 1: Synthesis of MPPzs 5a-h.

In continuation of our study to develop new procedures in various types of chemical transformations [37-41], herein, we wish to study the synthesis of MPPzs $(\mathbf{5 a}-\mathbf{h})$ by a one-pot coupling reaction of 2,3-diaminomaleonitrile (1), various 1,2dicarbonyl compounds (2), urea (3), and metal salts (4) under microwave irradiation conditions (Scheme 1).

\section{Results and Discussion}

In a typical experiment, the synthesis of MPPzs was carried out by mixing 2,3-diaminomaleonitrile 1 ( $1 \mathrm{mmol}$ ) with 1,2 dicarbonyl compounds 2 ( $1 \mathrm{mmol})$, urea 3 (4 mmol), and metal salts 4 ( $0.5 \mathrm{mmol})$ under microwave irradiation conditions. In this step, the reaction conditions were optimized with various molar ratios of raw materials. It was found that, the molar ratio of $1: 1: 4: 0.5$ from $1: 2: 3: \mathrm{CuCl}_{2} \cdot 2 \mathrm{H}_{2} \mathrm{O}$ obtained the best results under microwave irradiation conditions. As the reaction proceeded after $5 \mathrm{~min}$ colorful solid gradually appeared at medium power level option of microwave oven. After completion of the reaction, the crude product was washed with water and filtered off and the solid residue purified further by washing with $\mathrm{EtOH}$ to give pure $\mathrm{MPPz}$ of $5 \mathbf{a}$ in $80 \%$ yield. It is important to note that in the absence of $\mathrm{CuCl}_{2} \cdot 2 \mathrm{H}_{2} \mathrm{O}$ or urea the yield of reaction intensively decreased. In addition, excess amounts of them did not increase the yield of the reaction considerably.

To explore the scope and limitations of the reaction, the optimized protocol was applied to other substrates. The procedure was extended to various raw materials and different metal salts such as $\mathrm{CoCl}_{2}, \mathrm{FeCl}_{2} \cdot 4 \mathrm{H}_{2} \mathrm{O}$, and $\mathrm{ZnCl}_{2}$. As can be seen from Table 1, the different starting materials are converted to MPPzs in good yields after 5-10 $\mathrm{min}$. In general, these results showed that the $\mathrm{CuCl}_{2} \cdot 2 \mathrm{H}_{2} \mathrm{O}$ among metal salts and 1,2-bis(4-methoxyphenyl) ethane-1,2-dione within dicarbonyl compounds produce the best yields.

PPzs of metal salt are prepared efficiently from 1,2bis(4-methoxyphenyl) ethane-1,2-dione. However, synthesis of these compounds from biacetyl was not so successful and yields of the reaction were lower than the other derivatives. As a result, the reaction gave excellent results in the cases of using aromatic 1,2-dione, independently of the metal salts.
In comparison with the previously reported multistep procedures [17, 18, 26, 42], this work has some advantages such as higher yields, atom economy, and mild reaction conditions. Furthermore, our protocol does not require any protection/deprotection of functional groups (Scheme 2) [42].

In summary, we have described an efficient microwaveassisted procedure for the synthesis of porphyrazine derivatives carrying six membered pyrazine rings annulated at the periphery of the tetrapyrrolic macrocycle starting from simple and readily available precursors including 2,3diaminomaleonitrile, 1,2-dicarbonyl compounds, metal salts, and urea. This new multicomponent protocol for the preparation of synthetically, biologically, and technologically relevant MPPzs includes some important aspects like the fast and simple reaction, easy workup procedure, and high atom economy.

\section{Experimental}

3.1. Materials and Equipment. All solvents, chemicals, and reagents were purchased from Merck, Fluka, and SigmaAldrich international chemical companies. Melting points were measured on an Electrothermal 9200 apparatus and are uncorrected. IR and UV-Vis spectra were recorded with a Shimadzu IR-470 spectrometer and UV-Vis Shimadzu 2100, respectively. The elemental analyses were performed with an Elementar Analysensysteme GmbH VarioEL. The microwave oven was a Samsung model GE-4020W (max. 900 W) with five power level options (option used for this experiment: medium $50 \%$ power).

3.2. General Procedure for the Preparation of MPPzs (5ah). 2,3-Diaminomaleonitrile (1 mmol), 1,2-dicarbonyl compound $(1 \mathrm{mmol})$, metal salt $(0.5 \mathrm{mmol})$, and urea $(4 \mathrm{mmol})$ were taken in a round bottomed flask. Then, the resulting mixture was irradiated in a domestic microwave oven at medium state for appropriate time. As the reaction proceeded, colorful solid gradually appeared. After completion of the reaction, the crude product was washed with water ( 4 $\times 10 \mathrm{~mL}$ ) to give dark-green solid. Then, the precipitated solid 
TABLE 1: Microwave-assisted synthesis of MPPzs 5a-h.

\begin{tabular}{lcccc}
\hline Product & $\mathrm{R}$ & $\mathrm{MX}_{n}$ & Time (min) & Yield $^{\mathrm{a}}(\%)$ \\
\hline $\mathbf{5 a}$ & $\mathrm{CH}_{3}$ & $\mathrm{CuCl}_{2} \cdot 2 \mathrm{H}_{2} \mathrm{O}$ & 5 & 80 \\
$\mathbf{5 b}$ & $p-\mathrm{CH}_{3} \mathrm{O}-\mathrm{C}_{6} \mathrm{H}_{4}$ & $\mathrm{CuCl}_{2} \cdot 2 \mathrm{H}_{2} \mathrm{O}$ & 6 & 78 \\
$\mathbf{5 c}$ & $\mathrm{CH}_{3}$ & $\mathrm{CoCl}_{2}$ & 10 & 68 \\
$\mathbf{5 d}$ & $p-\mathrm{CH}_{3} \mathrm{O}-\mathrm{C}_{6} \mathrm{H}_{4}$ & $\mathrm{CoCl}_{2}$ & 7 & 74 \\
$\mathbf{5 e}$ & $\mathrm{CH}_{3}$ & $\mathrm{FeCl}_{2} \cdot 4 \mathrm{H}_{2} \mathrm{O}$ & 10 & 65 \\
$\mathbf{5 f}$ & $p-\mathrm{CH}_{3} \mathrm{O}-\mathrm{C}_{6} \mathrm{H}_{4}$ & $\mathrm{FeCl}_{2} \cdot 4 \mathrm{H}_{2} \mathrm{O}$ & 8 & 73 \\
$\mathbf{5 g}$ & $\mathrm{CH}_{3}$ & $\mathrm{ZnCl}_{2}$ & 10 & 66 \\
$\mathbf{5 h}$ & $p-\mathrm{CH}_{3} \mathrm{O}-\mathrm{C}_{6} \mathrm{H}_{4}$ & $\mathrm{ZnCl}_{2}$ & 8 & 70 \\
\hline
\end{tabular}

${ }^{\mathrm{a}}$ Isolated yield.<smiles>N#CC(N)=C(N)C#N</smiles><smiles>[R]C(=O)C([R])=O</smiles>

Scheme 2: Reported multistep synthesis of MPPzs.

was dried under vacuum and the solid residue was purified by washing three times in boiling EtOH $(3 \times 5 \mathrm{~mL})$ until the filtrate was colorless. The solid was dissolved in DMF and filtered through a cartridge filter to remove any inorganic impurities that may have been present. Concentration of the filtrate afforded $\mathbf{5} \mathbf{a}-\mathbf{h}$ as dark green to blue solids.

The prepared compounds were known and the data are comparable to the literature reports $[17,18,26,42]$.

3.3. Characterization of the Products. 5a: Dark blue solid; $\mathrm{mp}$ $>200^{\circ} \mathrm{C}$. IR (KBr): $v, \mathrm{~cm}^{-1} 1604(\mathrm{~m}), 1500(\mathrm{w}), 1457(\mathrm{~m}), 1415$ (m), $1328(\mathrm{w}), 1282(\mathrm{~m}), 1166(\mathrm{~s}), 1085(\mathrm{~m}), 1067(\mathrm{~m}), 897(\mathrm{~m})$, $871(\mathrm{~m}), 799(\mathrm{~s}), 775(\mathrm{~m}), 752(\mathrm{w}) . \mathrm{UV}-\mathrm{Vis}$ (DMSO): $\lambda_{\max }, \mathrm{nm}$ 638, 556, 445. Anal. Calcd for $\mathrm{C}_{32} \mathrm{H}_{24} \mathrm{CuN}_{16}$ : C, 55.21; H, 3.47; N, 32.19. Found C, 55.34; H, 3.56; N, 32.10. 5b: Dark blue solid; $\mathrm{mp}>200^{\circ} \mathrm{C}$. IR (KBr): $v, \mathrm{~cm}^{-1} 1602$ (m), $1500(\mathrm{w}), 1457(\mathrm{~m}), 1415(\mathrm{~s}), 1328(\mathrm{w}), 1282(\mathrm{~m}), 1166(\mathrm{~s})$, $1085(\mathrm{~m}), 1067(\mathrm{~m}), 897(\mathrm{~m}), 871(\mathrm{~m}), 799(\mathrm{~s}), 775(\mathrm{w}), 752$ (w). UV-Vis (DMSO): $\lambda_{\max }, \mathrm{nm} 655,564,457$. Anal. Calcd for $\mathrm{C}_{80} \mathrm{H}_{56} \mathrm{CuN}_{16} \mathrm{O}_{8}$ : C, 67.05; H, 3.94; N, 15.64. Found C, 67.12; $\mathrm{H}, 4.08 ; \mathrm{N}, 15.53$.

5c: Dark greenish blue solid; $\mathrm{mp}>200^{\circ} \mathrm{C}$. IR $(\mathrm{KBr}): v$, $\mathrm{cm}^{-1} 1604(\mathrm{~m}), 1515(\mathrm{w}), 1485(\mathrm{~m}), 1420(\mathrm{~s}), 1326(\mathrm{~s}), 1284(\mathrm{~m})$, $1153(\mathrm{w}), 1085(\mathrm{~s}), 1024(\mathrm{~m}), 948(\mathrm{~m}), 910(\mathrm{w}), 871(\mathrm{~m}), 778(\mathrm{~s})$, 756 (m). UV-Vis (DMSO): $\lambda_{\max }, \mathrm{nm} 615,597,420$. Anal. Calcd for $\mathrm{C}_{32} \mathrm{H}_{24} \mathrm{CoN}_{16}$ : C, 55.58; $\mathrm{H}, 3.50 ; \mathrm{N}, 32.41$. Found C, 55.63; $\mathrm{H}, 3.46 ; \mathrm{N}, 32.58$.

5d: Dark green solid; $\mathrm{mp}>200^{\circ} \mathrm{C}$. IR $(\mathrm{KBr}): v, \mathrm{~cm}^{-1} 1604$ (m), $1516(\mathrm{w}), 1484(\mathrm{~m}), 1420(\mathrm{~s}), 1326(\mathrm{~m}), 1284(\mathrm{~s}), 1153(\mathrm{~m})$, $1115(\mathrm{~s}), 1085(\mathrm{w}), 1024(\mathrm{~m}), 948(\mathrm{w}), 912(\mathrm{~m}), 871(\mathrm{w}), 778$ (s), 756 (m). UV-Vis (DMSO): $\lambda_{\max }, \mathrm{nm}$ 625, 617, 426. Anal. 
Calcd for $\mathrm{C}_{80} \mathrm{H}_{56} \mathrm{CoN}_{16} \mathrm{O}_{8}$ : C, 67.27; $\mathrm{H}, 3.95 ; \mathrm{N}, 15.69$. Found C, 67.36; H, 4.13; N, 15.52 .

5e: Light olive gray solid; $\mathrm{mp}>200^{\circ} \mathrm{C}$. IR $(\mathrm{KBr}): v$, $\mathrm{cm}^{-1} 1601(\mathrm{~m}), 1478$ (w), 1448 (m), 1404 (s), 1327 (m), 1278 (s), $1152(\mathrm{~m}), 1112(\mathrm{w}), 1087(\mathrm{w}), 884(\mathrm{~m}), 775$ (s), $748(\mathrm{~m})$. UV-Vis (DMSO): $\lambda_{\text {max }}, \mathrm{nm}$ 654, 645, 569. Anal. Calcd for $\mathrm{C}_{32} \mathrm{H}_{24} \mathrm{FeN}_{16}$ : C, 55.82; H, 3.51; N, 32.55. Found C, 55.93; H, $3.42 ; \mathrm{N}, 32.67$.

5f: Light olive gray solid; $\mathrm{mp}>200^{\circ} \mathrm{C}$. IR $(\mathrm{KBr}): v, \mathrm{~cm}^{-1}$ 1601 (m), 1478 (w), 1448 (m), 1404 (s), 1327 (s), 1278 (m), 1150 (w), 1088 (m), 884 (w), 775 (s), 749 (m). UV-Vis (DMSO): $\lambda_{\text {max }}$, nm 668, 662, 575. Anal. Calcd for $\mathrm{C}_{80} \mathrm{H}_{56} \mathrm{FeN}_{16} \mathrm{O}_{8}: \mathrm{C}$, 67.42; H, 3.96; N, 15.72. Found C, 67.56; H, 4.15; N, 15.67.

5g: Light greenish blue solid; $\mathrm{mp}>200^{\circ} \mathrm{C}$. IR $(\mathrm{KBr}): v$, $\mathrm{cm}^{-1} 1600$ (m), 1462 (s), 1416 (s), 1325 (m), 1282 (w), 1158 (m), $1112(\mathrm{~m}), 1065(\mathrm{w}), 948(\mathrm{~m}), 864(\mathrm{w}), 775(\mathrm{~s}), 752(\mathrm{~m})$. UV-Vis (DMSO): $\lambda_{\max }, \mathrm{nm} 642,563,414$. Anal. Calcd for $\mathrm{C}_{32} \mathrm{H}_{24} \mathrm{~N}_{16} \mathrm{Zn:}$ C, 55.06; H, 3.47; N, 32.10. Found C, 54.98; H, 3.52; N, 32.27.

5h: Dark greenish blue solid; $\mathrm{mp}>200^{\circ} \mathrm{C}$. IR $(\mathrm{KBr}): v$, $\mathrm{cm}^{-1} 1600(\mathrm{~m}), 1462$ (s), $1415(\mathrm{~m}), 1325$ (s), $1282(\mathrm{~m}), 1158(\mathrm{w})$, 1112 (m), 1065 (m), 948 (w), 864 (m), 775 (s), 752 (w). UVVis (DMSO): $\lambda_{\max }, \mathrm{nm} 658,602,498,388$. Anal. Calcd for $\mathrm{C}_{80} \mathrm{H}_{56} \mathrm{~N}_{16} \mathrm{O}_{8} \mathrm{Zn}: \mathrm{C}, 66.97 ; \mathrm{H}, 3.93 ; \mathrm{N}, 15.62$. Found C, 67.06; $\mathrm{H}, 4.10 ; \mathrm{N}, 15.53$.

\section{Conflict of Interests}

The authors declare that there is no conflict of interests regarding the publication of this paper.

\section{Acknowledgment}

The authors would like to thank partial support from the Research Council of the Iran University of Science and Technology.

\section{References}

[1] "Phthalocyanines: properties and materials," in The Porphyrin Handbook, K. M. Kadish, K. M. Smith, and R. Guilard, Eds., vol. 17, Academic Press, San Diego, Calif, USA, 2003.

[2] H. J. Berthold, J. Thiem, A. Zaliani, and T. Schotten, "Spiroannelated Zn-phthalocyanine: a novel building block for molecular architecture?" Synthesis, vol. 20, pp. 3569-3575, 2010.

[3] D. Wöhrle, G. Schnurpfeil, S. G. Makarov, A. Kazarin, and O. N. Suvorova, "Practical applications of phthalocyaninesfrom dyes and pigments to materials for optical, electronic and photo-electronic devices," Macroheterocycles, vol. 5, pp. 191-202, 2012.

[4] R. M. Banavali and K. S. Ho, "Pyrazinoporphyrazines as markers for liquid hydrocarbons," US Patent 7157611, 2007.

[5] K. S. Suslick, N. A. Rakow, M. E. Kosal, and J.-H. Chou, "The materials chemistry of porphyrins and metalloporphyrins," Journal of Porphyrins and Phthalocyanines, vol. 4, pp. 407-413, 2000.

[6] Y. J. Li, Y. Fan, X. G. Ren et al., "Synthesis of a substituted phthalocyaninato-polysiloxane and its Langmuir-Blodgett films," Journal of Porphyrins and Phthalocyanines, vol. 2, no. 6, pp. 527-530, 1998.

[7] C. C. Leznoff and A. B. P. Lever, Phthalocyanines: Properties and Applications, vol. 3, VCH, New York, NY, USA, 1993.

[8] C. M. Drain, J. T. Hupp, K. S. Suslick, M. R. Wasielewski, and X. Chen, "A perspective on four new porphyrin-based functional materials and devices," Journal of Porphyrins and Phthalocyanines, vol. 6, no. 4, pp. 243-258, 2002.

[9] T. Sauer, W. Caseri, G. Wegner, A. Vogel, and B. Hoffmann, "Development of novel chemical sensor devices based on LB films from phthalocyaninato-polysiloxane polymers," Journal of Physics D, vol. 23, no. 1, pp. 79-84, 1990.

[10] S. Venugopal Rao and D. Narayana Rao, "Excited state dynamics in phthalocyanines studied using degenerate four wave mixing with incoherent light," Journal of Porphyrins and Phthalocyanines, vol. 6, no. 3, pp. 233-237, 2002.

[11] S. V. Rao, N. K. M. Naga Srinivas, D. N. Rao et al., "Excited state dynamics in tetra tolyl porphyrins studied using degenerate four wave mixing with incoherent light and ps pulses," Optics Communications, vol. 192, no. 1-2, pp. 123-133, 2001.

[12] S. V. Rao, N. K. M. N. Srinivas, D. N. Rao et al., "Studies of third-order optical nonlinearity and nonlinear absorption in tetra tolyl porphyrins using degenerate four wave mixing and Z-scan," Optics Communications, vol. 182, no. 1-3, pp. 255-264, 2000.

[13] R. Bonnett, "Photosensitizers of the porphyrin and phthalocyanine series for photodynamic therapy," Chemical Society Reviews, vol. 24, pp. 19-33, 1995.

[14] M. K. Nazeeruddin, R. Humphry-Baker, D. L. Officer, W. M. Campbell, A. K. Burrell, and M. Grätzel, "Application of metalloporphyrins in nanocrystalline dye-sensitized solar cells for conversion of sunlight into electricity," Langmuir, vol. 20, no. 15, pp. 6514-6517, 2004.

[15] W. M. Campbell, A. K. Burrell, D. L. Officer, and K. W. Jolley, "Porphyrins as light harvesters in the dye-sensitised $\mathrm{TiO}_{2}$ solar cell," Coordination Chemistry Reviews, vol. 248, no. 13-14, pp. 1363-1379, 2004.

[16] M. K. Nazeeruddin, R. Humphry-Baker, M. Grätzel, and B. A. Murrer, "efficient near IR sensitization of nanocrystalline $\mathrm{TIO}_{2}$ films by ruthenium phthalocyanines," Chemical Communications, vol. 6, pp. 719-720, 1998.

[17] P. A. Stuzhin and C. Ercolani, "Porphyrazines with annulated heterocycles," in The Porphyrin Handbook, K. M. Kadish, K. M. Smith, and R. Guilard, Eds., vol. 15, p. 263, Academic Press, New York, NY, USA, 2003.

[18] S. V. Kudrevich and J. E. van Lier, "Azaanalogs of phthalocyanine: syntheses and properties," Coordination Chemistry Reviews, vol. 156, pp. 163-182, 1996.

[19] K. Kopecky, D. Šatinský, V. Novakova, M. Miletin, A. Svoboda, and P. Zimcik, "Synthesis of mono-, di-, tri- and tetracarboxy azaphthalocyanines as potential dark quenchers," Dyes and Pigments, vol. 91, no. 2, pp. 112-119, 2011.

[20] S. Tomachynskyi, S. Korobko, L. Tomachynski, and V. Pavlenko, "Synthesis and spectral properties of new tetrakis-2,3-5,7bis[(E)-2-(4-methylphenyl)vinyl]pyrazinoporphyrazine metal complexes," Optical Materials, vol. 33, no. 10, pp. 1553-1556, 2011.

[21] M. J. Fuchter, C. Zhong, H. Zong, B. M. Hoffman, and A. G. M. Barrett, "Porphyrazines: designer macrocycles by peripheral substituent change," Australian Journal of Chemistry, vol. 61, no. 4, pp. 235-255, 2008. 
[22] E. R. Trivedi, B. J. Vesper, H. Weitman et al., "Chiral bis-acetal porphyrazines as near-infrared optical agents for detection and treatment of cancer," Photochemistry and Photobiology, vol. 86, no. 2, pp. 410-417, 2010.

[23] S. L. J. Michel, S. Baum, A. G. M. Barrett, and B. M. Hoffman, "Peripherally functionalized porphyrazines: novel metallomacrocycles with broad, untapped potential," Progress in Inorganic Chemistry, vol. 50, pp. 473-590, 2001.

[24] J. C. Maziere, R. Santus, P. Morliere et al., "Cellular uptake and photosensitizing properties of anticancer porphyrins in cell membranes and low and high density lipoproteins," Journal of Photochemistry and Photobiology B, vol. 6, no. 1-2, pp. 61-68, 1990.

[25] J. Osterloh and M. G. H. Vicente, "Mechanisms of porphyrinoid localization in tumors," Journal of Porphyrins and Phthalocyanines, vol. 6, no. 5, pp. 305-324, 2002.

[26] M. P. Donzello, C. Ercolani, and P. A. Stuzhin, "Novel families of phthalocyanine-like macrocycles-porphyrazines with annulated strongly electron-withdrawing 1,2,5-thia/selenodiazole rings," Coordination Chemistry Reviews, vol. 250, no. 11-12, pp. 1530-1561, 2006.

[27] C. J. Schramm and B. M. Hoffman, "Octakis(alkylthio) tetraazaporphyrins," Inorganic Chemistry, vol. 19, pp. 383-385, 1980.

[28] C. S. Velazquez, W. E. Broderick, M. Sabat, A. G. M. Barrett, and B. M. Hoffman, "Metal-encapsulated porphyrazines: synthesis, $\mathrm{x}$-ray crystal structure and spectroscopy of a tetratinstar-nickel(porphyrazine)S8 complex," Journal of the American Chemical Society, vol. 112, pp. 7408-7410, 1990.

[29] E. G. Sakellariou, A. G. Montalban, H. G. Meunier et al., "Synthesis and photophysical properties of peripherally metallated bis(dimethylamino)porphyrazines," Journal of Photochemistry and Photobiology A, vol. 136, no. 3, pp. 185-187, 2000.

[30] J. Fitzgerald, W. Taylor, and H. Owen, "Facile synthesis of substituted fumaronitriles and maleonitriles: precursors to soluble tetraazaporphyrins," Synthesis, no. 9, pp. 686-688, 1991.

[31] J. P. Fitzgerald, B. S. Haggerty, A. L. Rheingold, L. May, and G. A. Brewer, "Iron octaethyltetraazaporphyrins: synthesis, characterization, coordination chemistry, and comparisons to related iron porphyrins and phthalocyanines," Inorganic Chemistry, vol. 31, no. 11, pp. 2006-2013, 1992.

[32] M. E. Anderson, S. Baum, A. G. M. Barrett, and B. M. Hoffman, "Super-charged porphyrazines: synthesis and physical properties of octacationic tetraazaporphyrins," Inorganic Chemistry, vol. 38, pp. 6143-6151, 1999.

[33] M. Polat and A. Gül, "Synthesis of new porphyrazines with tertiary or quaternized aminoethyl substituents," Dyes and Pigments, vol. 45, no. 3, pp. 195-199, 2000.

[34] R. Z. U. Kobak, E. S. Öztürk, A. Koca, and A. Gül, "The synthesis and cyclotetramerisation reactions of aryloxy,arylalkyloxy-substituted pyrazine-2,3-dicarbonitriles and spectroelectrochemical properties of octakis(hexyloxy)pyrazinoporphyrazine," Dyes and Pigments, vol. 86, pp. 115-122, 2010.

[35] Q. Gan, F. Xiong, S. Li et al., "Synthesis and photophysical properties of a series of octaphenyl-porphyrazine-magnesium," Inorganic Chemistry Communications, vol. 8, pp. 285-288, 2005.

[36] A. Loupy, Microwave in Organic Synthesis, Wiley-VCH, Weinheim, Gemany, 2002.

[37] A. Maleki, " $\mathrm{Fe}_{3} \mathrm{O}_{4} / \mathrm{SiO}_{2}$ nanoparticles: an efficient and magnetically recoverable nanocatalyst for the one-pot multicomponent synthesis of diazepines," Tetrahedron, vol. 68, pp. 7827-7833, 2012.
[38] A. Maleki, "One-pot multicomponent synthesis of diazepine derivatives using terminal alkynes in the presence of silicasupported superparamagnetic iron oxide nanoparticles," Tetrahedron Letters, vol. 54, pp. 2055-2059, 2013.

[39] A. Shaabani, A. Maleki, and J. Moghimi-Rad, "A novel isocyanide-based three-component reaction: synthesis of highly substituted 1,6-dihydropyrazine-2,3-dicarbonitrile derivatives," Journal of Organic Chemistry, vol. 72, pp. 6309-6311, 2007.

[40] A. Shaabani, A. Maleki, H. Mofakham, and J. Moghimi-Rad, "A novel one-pot pseudo-five-component synthesis of 4,5,6,7tetrahydro-1H-1, 4-diazepine-5-carboxamide derivatives," Journal of Organic Chemistry, vol. 73, no. 10, pp. 3925-3927, 2008.

[41] A. Shaabani and J. Maleki, "Rapid and efficient synthesis of metal-free phthalocyanine derivatives," Porphyrins Phthalocyanines, vol. 10, p. 1253, 2006.

[42] E. M. Bauer, C. Ercolani, P. Galli, I. A. Popkova, and P. A. Stuzhin, "Tetrakis(selenodiazole)porphyrazines-1: tetrakis (selenodiazole)porphyrazine and its $\mathrm{Mg}(\mathrm{II})$ and $\mathrm{Cu}(\mathrm{II})$ Derivatives. Evidence for their Conversion to Tetrakis(pyrazino)porphyrazines through Octaaminoporphyrazines," Journal of Porphyrins and Phthalocyanines, vol. 3, no. 5, pp. 371-379, 1999. 

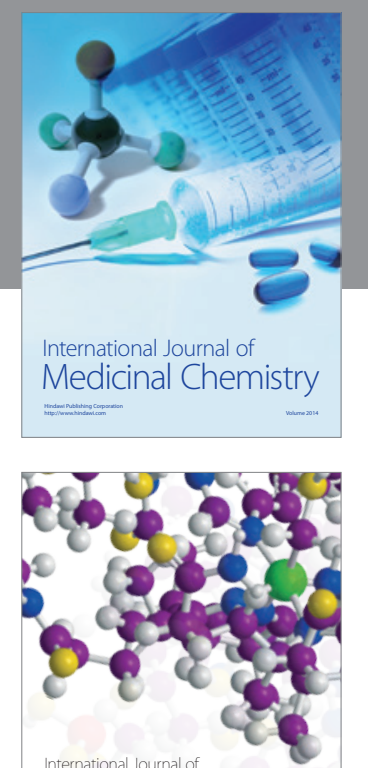

\section{Carbohydrate} Chemistry

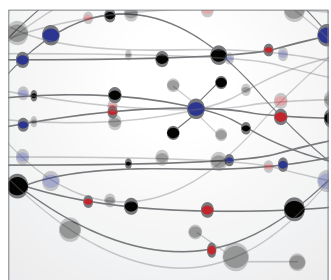

The Scientific World Journal
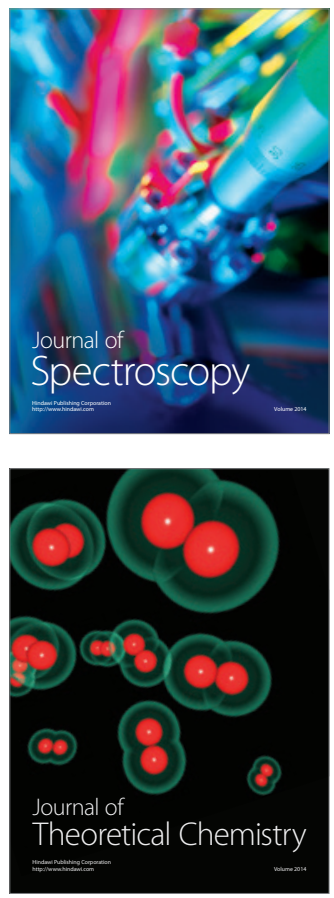
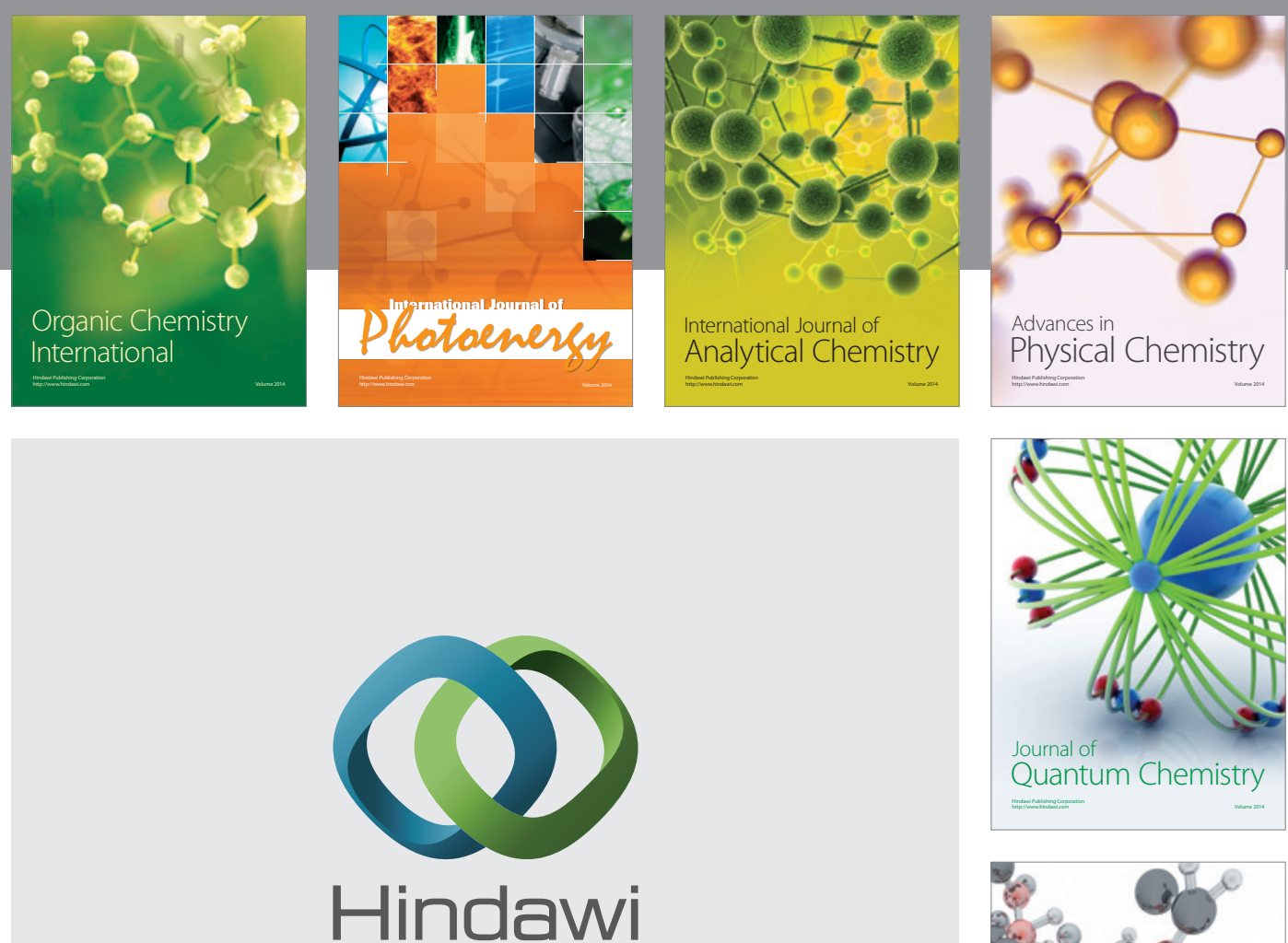

Submit your manuscripts at

http://www.hindawi.com

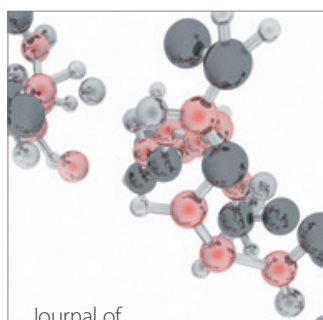

Analytical Methods

in Chemistry

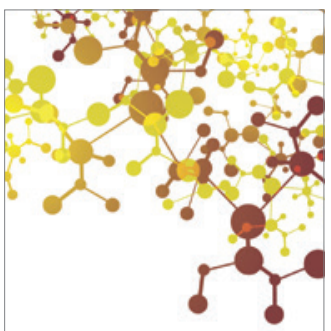

Journal of

Applied Chemistry

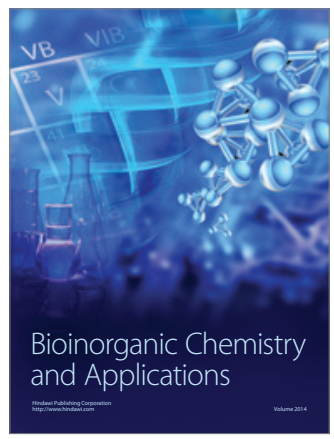

Inorganic Chemistry
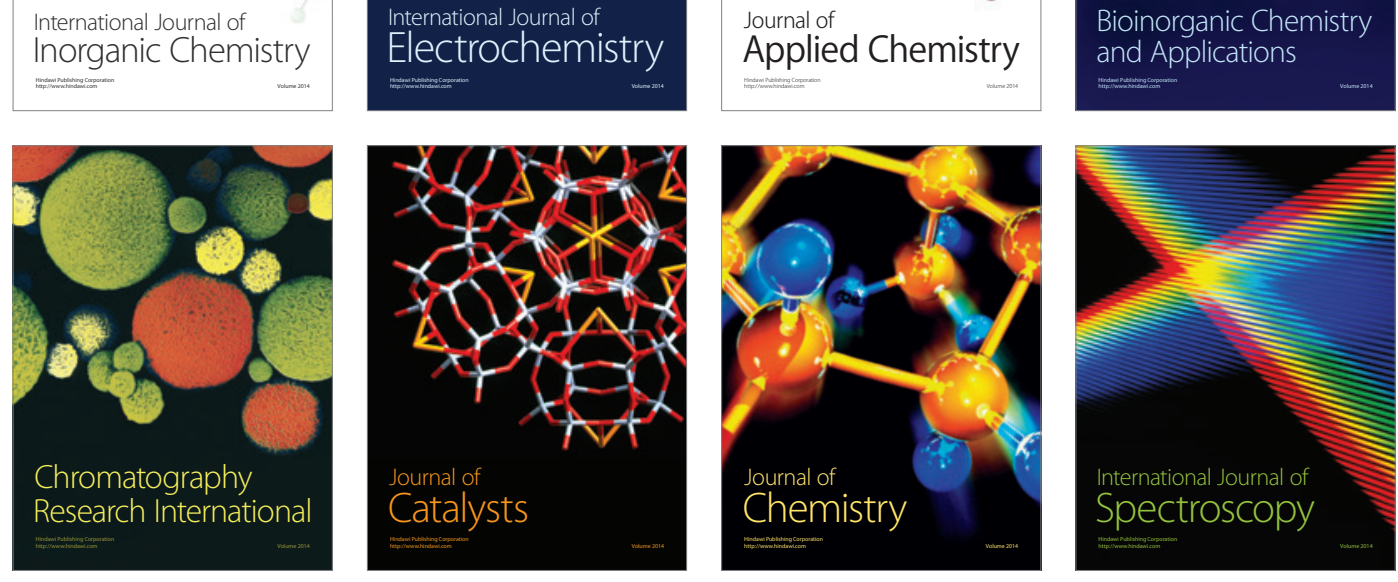